\title{
Strategic Moves of the War, November 24th, 1915
}

\author{
By Lieut. J. B. W. Gardiner, Formerly of the 11th Cavalry, U. S. A.
}

$W_{\text {and their diplomats have made unceasing efforts }}^{\text {HILE the capitals of the Allies have woried }}$ to direct the unruly current of affairs in the Balkans more and more Serbian territory has been captured and occupied by the Teutons and the Bulgars. In fact but a small proportion still remains with the Serbians, and as they continue to be driven back, the flanks of the invaders' armies are drawing nearer and nearer together, their battle line becoming denser and denser, and the ability to resist them less and less. Only a mall section of old Serbia still remains and it seems inevitable that the Serbian army will be completely broken up, and, driven into the wilds of Montenegro and Albania, will resolve itself into a number of small bands, acting independently. There seems no hope of any other outcome. As this article is being written the Serbs are making what will probably prove to be their last stand, on the historic plains of Kossovo. But it must be evident that such a stand if successful at all can be so only for a short time. The fact that they are fighting on a short line is of course to their advantage. But the disparity in numbers is too great, and the Serbs, in probably not more than two weeks time, will see all of their country except the newly old and new will have to be abandoned to the Teutons and the Bulgars. There is no possibility to enlist Greek aid. In fact it would be suicidal for Greece to declare for the Allies at this juncture. The time has gone by when her assistance would have solved the Allies' problem. Now Greece finds herself with a strong Bulgarian force almost immediately on her border, and a still stronger force of Teutons and Bulgarians advancing from the north and not so very far distant. To declare for the Allies now would simply be to invite in vasion by a force, which, even with the assistance of the Allies, Greece would find it impossible to repel.

As time passes it grows increasingly difficult to understand just what this invasion of Serbia portends. The gateway from Berlin to Constantinople is open, it is true, but then what? Lack of transportation facilities and the long line of communications that would have to be guarded makes an operation against Egypt almost impossible. The Teutons, even with such assistance as the Turks can give, cannot hope to hold another line over fifteen hundred miles long. Turkey cannot feed Germany. Her crop of cereals is but little more than sufficient to support her own population. Bulgaria of course, has in storage two years' wheat crops, but natural. There has been nothing in these fields to appeal to the imagination, surfeited as it has become with startling, dramatic victories, first of one side, and then the other. The Italian advance has been slow, painfully slow to those who, not realizing topographical conditions nor the defensive possibilities of the Alps and Dolomities on the west or the Isonzo on the east, felt that as soon as Italy threw down the gauntlet her troops would fight their way steadily and without delay to Trent and Trieste. But the mountains of Trentino have always been regarded by the military men of Europe as an insuperable obstacle, effectually preventing any offense and of themselves constituting at least 75 per cent of Austria's defensive strength against an attack coming from either east, west or south. This is readily apparent to anyone who has passed from Geneva, Lausanne or Basle in Switzerland through Trentino to Milan, Venice or Brona. The valleys are narrow, so narrow at times that the railroad right of way passes on rock ledges cut into the mountain sides. The sides of the mountains are almost perpendicular and their snow-capped tops like an irregular mass of rough, jagged, gigantic teeth projecting upward into the skies. In such a country an effective connected in-

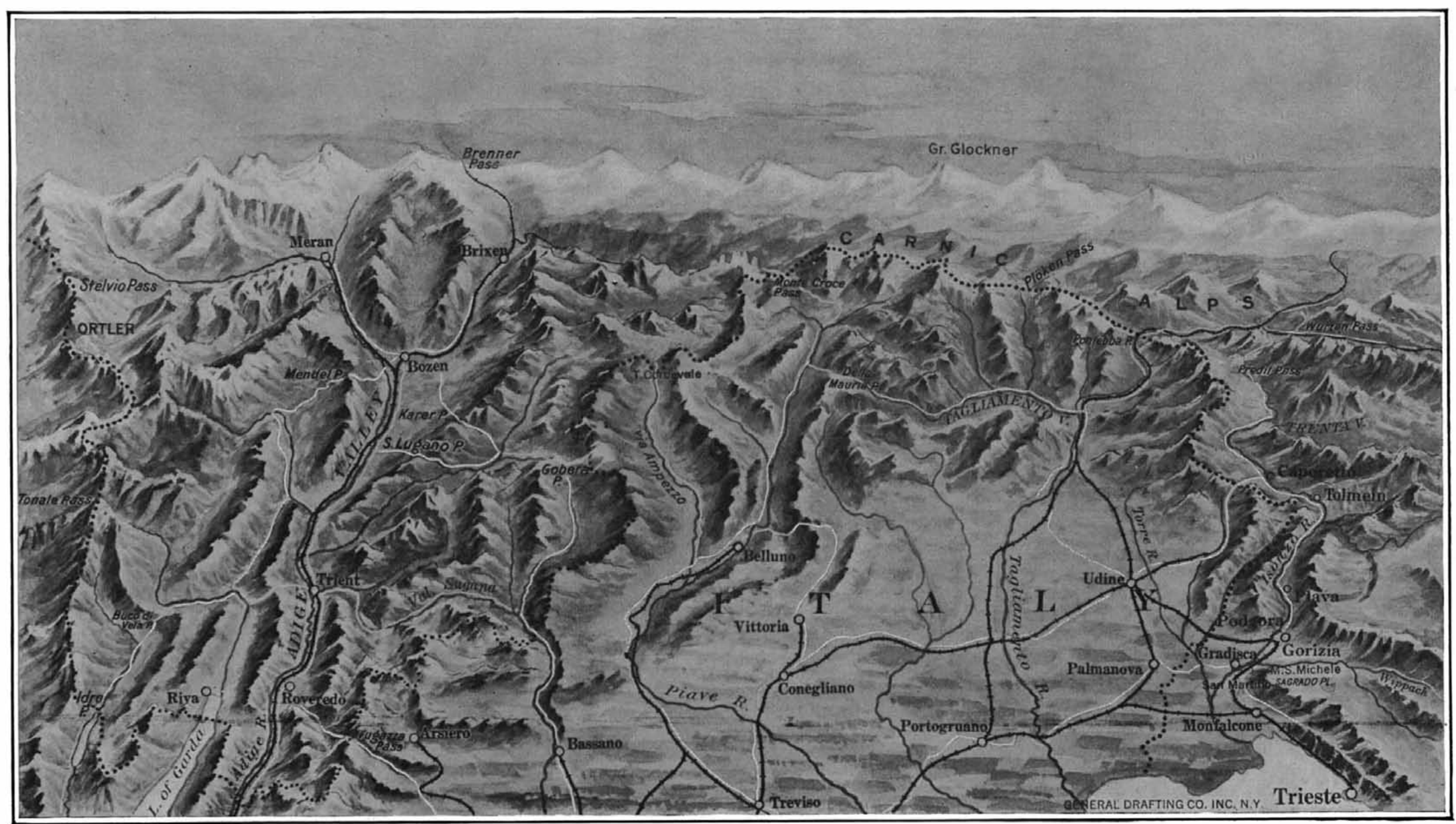

Bird's-eye view of the Austro-Italian battle fields in the Alps

gained Macedonia, pass from them. Already the Teuton line extends parallel to the Montenegrin frontier from Prjepalje to Novo Pasor, and from there to Lesowatz, and in the Tetowo district it extends, after coming down the railroad to Uskub, almost to the Albanian frontier. From Uskub to the Katschanik Pass the railroad of the Iban valley is entirely in Bulgarian hands, thus barring the retreat of the Serbians into Macedonia and preventing the Allies in Macedonia from sending help north. Just why the Allies delayed so long in sending help, why the Serbs were all concentrated in the north while the vital part of the whole defensive scheme is the railroad in the south from Saloniki to Uskub, will probably always remain a mystery. It is openly hinted, that it is because of a secret understanding with Constantine whereby he was to add 150,000 Greeks to the Allied armies as soon as an equal number of .French and British had landed at Saloniki, which understanding the Greek king has disregarded. The result is that not only are the troops in old Serbia doomed, but the French and British forces in Macedonia are unable to hold their own with the increasing numbers of Bulgarian troops. By the capture of Babuna Pass, the French line along the border has been outflanked and at some points has been forced back. It seems inevitable that all of the Allies will be driven across the Greek frontier and that Serbia, and this is now available to Germany-at a price. But this latest move puts an added drain not only on German reserves, but on German finance, and Germany has already borrowed more money for this war than all the Allies combined. It is difficult, then, to see anything else in the Serbian invasion than a political rather than a military undertaking, which has for its object the creation of a sentiment throughout the world that Germany is invincible, that there is no military undertaking the German armies cannot accomplish And then will come talk of peace. There can be no question but that Germany wants peace and needs it. To face a winter in her present position in Russia, with the Cza recruiting new millions from his inexhaustible reserve, accumulating a greater supply of ammunition than he has yet had and organizing and welding his enormous resources is a picture not pleasant for Germany to contemplate. Conquering the Serbians will add no com fort when the spring comes. It would surprise no one, then, when a decision has been gained over the Serbs, and it undoubtedly will, to see the press of the neutral world filled with hints and suggestions of peace, care fully placed by the German Publicity Bureau.

So completely has public attention been absorbed in the tragedy of the subjugation of Serbia to Teuton arms, that the operations in the Italian theatres-in Trentin and in Carso, have received but scant attention. This is vasion is obviously impossible and Italy has of course never attempted it. Her problem did not demand it. On the north and in part on the east also, as well as on the west, Italy is practically hidden from the rest of the warring nations by the same sort of a screen of almost impassable mountains. These mountains open into Piedmont, Lombardy and Venetia by means of passes through which troops invading any one of these provinces must come. It is only in the southeastern part of the Province of Venetia, along the lower Isonzo, that the country opens up sufficiently to admit of military operations on a large scale. It is here therefore, with Trieste as the objective, that the great Italian offensive has been launched.

Before, however, such a move could be pushed the Austrians who were in the Trentino in force, had to be neutralized. Otherwise the Austrians would pour through the mountain passes directly on the flank and rear of the troops on the Isonzo line. This part of her task Italy has accomplished with great thoroughness. As far as their ability to invade Italy is concerned, the Austrians in Trentino might just as well be fighting with the Germans on the Gulf of Riga. Every outlet from Trentino has been effectively closed. Beginning on the west, where the Trentino boundary joins that of Switzerland, these outlets are the Stelio (Concluded on page 507) 


\section{FUR' [EAKYY YUNDERS"

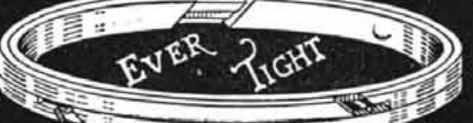 \\ PISTIN RINAS

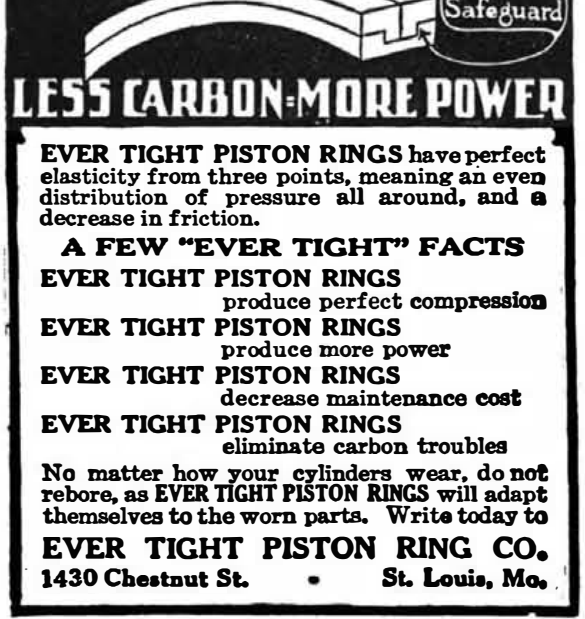

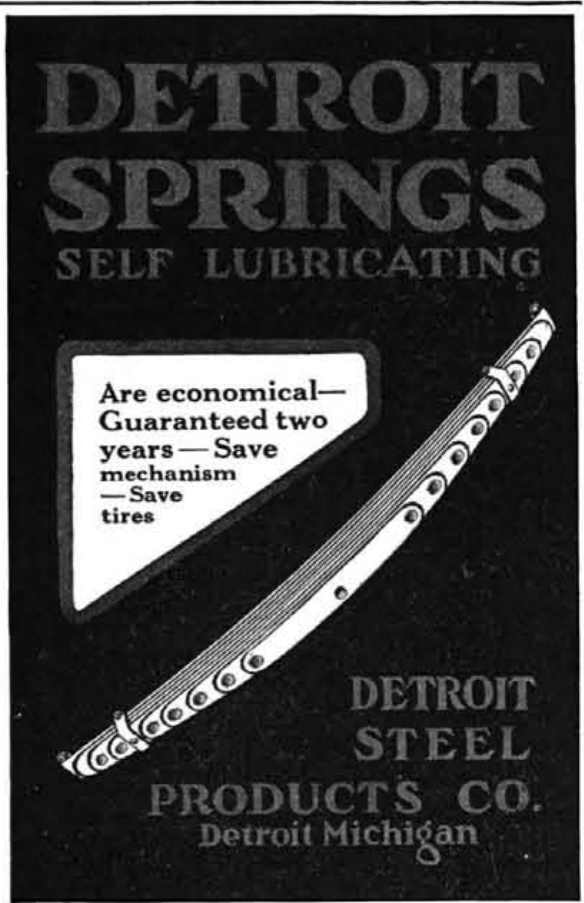

VEEDER CLUTCH COUNTER No. 21

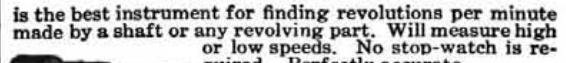

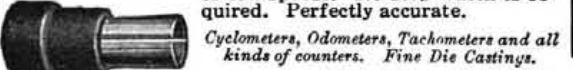

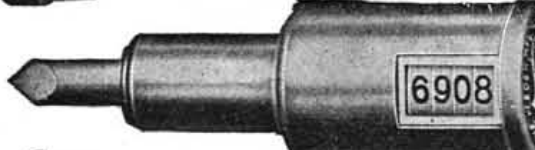

Cat 3\% Slis
Veeder Mfg. Co. Prleo \$3
18 Sargeant St., Hartford, Conn.

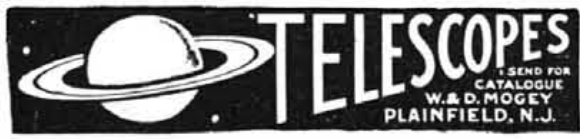

My \$3 Exerciser \$100 Reduced to

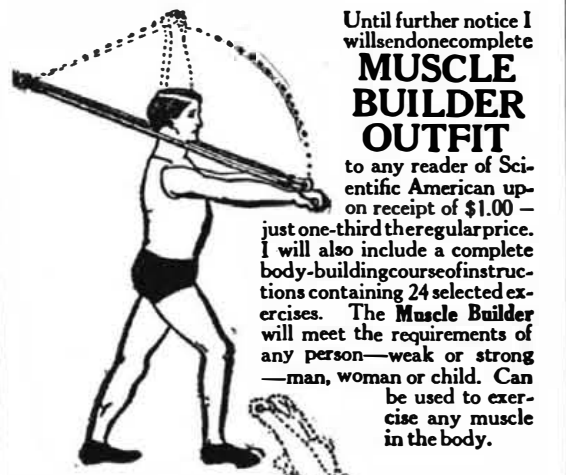
A Chest

Expander Also

with each outfit, A will give
an extra handle without charge, by which the Muecle
Builder can instantly becon
certed into a most effective Chest Expander to be used and lungs. Take advantage
of this opportunity while
it lasts. Send your order of this opportunity while
it lasts. Send your order
today.

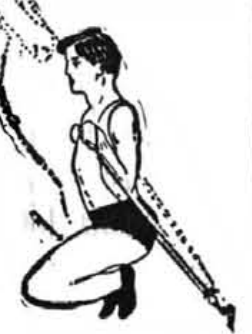

would render the Niagara project almost unique among the world's great sources of would not much exceed the lowest record viz., the rate of $\$ 2$ per annum in Iceland, or of $\$ 3$ on the West Coast of Norway. It is doubtful whether the initial outwould mean a capital outlay of $\$ 27$ per annual horse-power; or an annual interest charge of less than $\$ 1.75$.

What would this all mean for the regions adjacent, for southern Ontario and for western New York? In a recent the American Electro-Chemical Society, Prof. Norton eloquently answered the "I dustrial metropolis, surpassing any now (he face of the globe. No sphere; no towering chimneys would rise gainst the sky-line. Industries of the most varied nature, dependent upon the electric current, would gravitate to this point. It would become in very truthAmerica !

Strategic Moves of the War, November 24th, 1915

Pass, Tonale Pass and the Val de Sole, Storo near Lake Idro; and on the eastern frontier at Arsiero, down the Val Sugana, and the Val Cordevale. Through these gaps trated, have taken the fortifications guarding their entrance, and occupy commanding positions well beyond their own border. At several points they have gone well Notable among these are at Storo, where they have directed an offense aimed at Riva and down the Val Sugana, and its outhwest branches towards Roveredo. the former at the head of Lake Garda, the latter in the valley of the Adige, guarding the approach up that valley to Trenc. In the Riva section they moved eastward along the valley of the Ponale river, a small stream connecting Lake Idro with Lake Garda, containing several waterfalls which supply Riva with power for its lighting system. The Ponale is in Italian hands for its entire length and the Italian forces are within two miles of the city gana has not met with the same degree of success. Although many important height miles distant from the city and apparently are content to hold what they have army on the Isonzo. Farther north in the Val Cordevale, particularly about the tivity, but this mountain is so far moved from the Adige Valley that its influence on the operations directed at Riva ovedo and Trent is practically nil. tino operations are essentially defensive in character, the true offense being conducted along the southern Isonzo. Along the front the Austrians have been satisfied to remain altogether in a defensive attude. The demands for men have been not been able to send enough men into the Italian field to operate on any other seen from the accompanying map, rememseen from the accompanying map, rememis the city of Trieste. It is perfectly obvious that an advance on that city must first involve the reduction of the fortified camp at Gorizia. Otherwise the by an attack on the Italian line of communications render nugatory any offensive the Italians might direct from any one of the cities to the south which have woudy fallen into their hands. This offense from Monfalcone, which would naturally follow the railroad line from that place to Trieste.

Gorizia itself is situated in a small flat plain, almost at the level of the river.

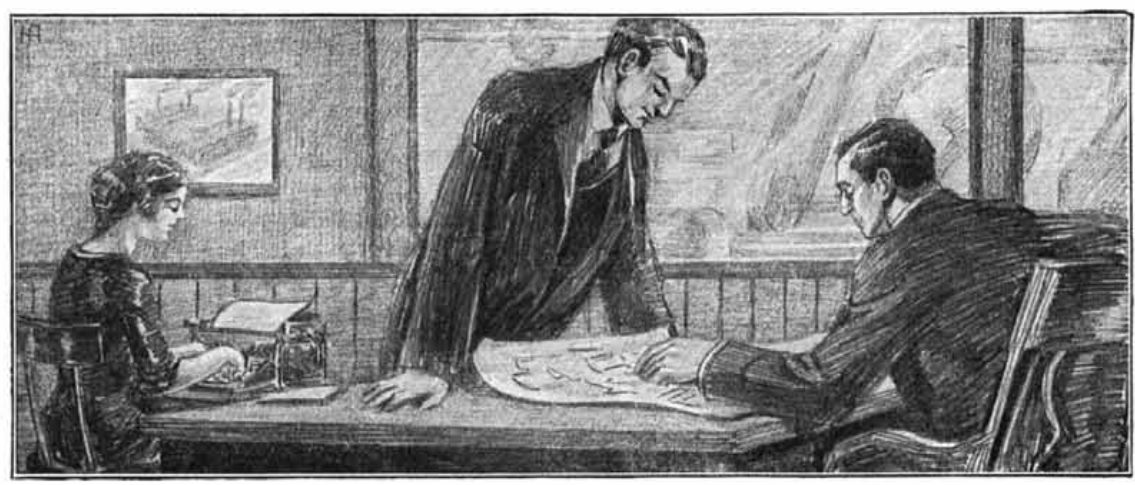

Let's Talk Your Power Problems Over Together

For over 20 years we have been solving the power problems for hundreds of manufacturers the country over. For over 20 years we have been successfully designing and bulding hind been built on one thing well done-motors. Think what the vast experience of our organization-learned in the vortex of every day motor practice and progress
might mean to you. What we have done in designing and building efficient and economical motor power units for others we can do for you.

ROTHMOTORS

\section{Mean Efficient Motors}

Roth motors and dynamos are built for one purpose only-steady, day in and day out, service. They are staunch in construction-simple in design. The No untried theories have a place on a Roth motor or dynamo. When you buy a Roth product you are securing the experience and skill of a score of motor masters -men who have dug deep into the vitals of every phase of motor driven machinery problems. When you buy a product bearing the Roth nameplate, you buy more than an ordinary motor or dynamo-you buy a piece of apparatus conforming to the highest point of modern efficiency. Hundreds of representative manufac-
turers in different lines will gladly back thisstatement. They know-by experience.

\section{For Every Business}

No matter whether your business is large or
(1)

small-highly technical or simple-

not, let us study your power problem.

Remember your delivered power
service is no more efficient than

the motor upon which

you depend to deliver
it. Inefficient motors and dynamos mean power waste-cost-
ly breakdowns-delays-money losses. You cannot afford to

take chances. Put

your power problem up

you quickly and without obliga

ROTH BROS. \&

ROTH BROS. \& CO. CHICAGO, ILL.

Agencies In All
Principal Cities
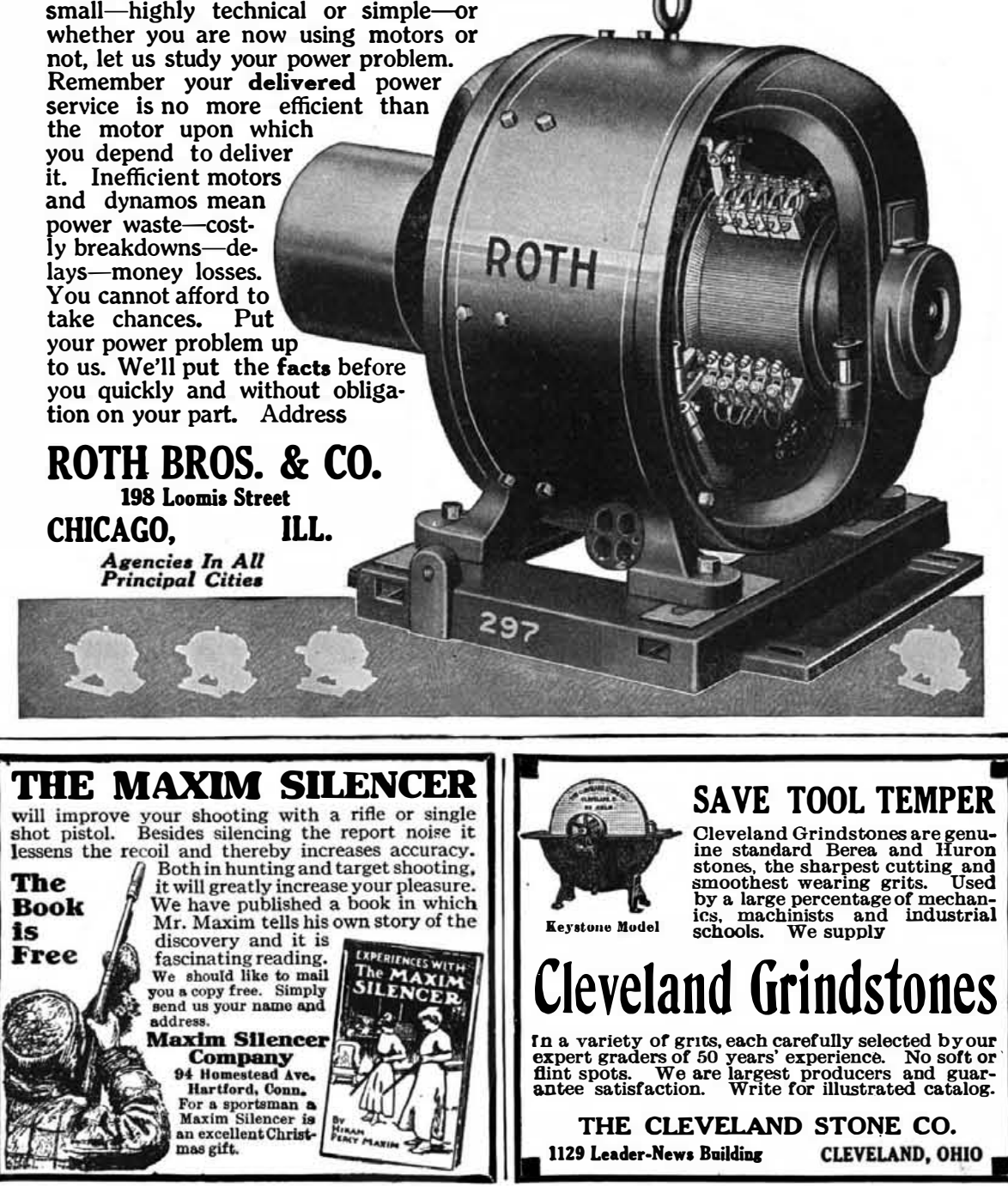

Cleveland Grindstones

in a variety of grits, each carefully selected by our expert graders of 50 years' experience. No solt or
fint spots. We are largest producers ad guar-
antee satisfaction. Write for illustrated catalog.

THE CLEVELAND STONE CO. 1129 Leader-News Building CLEVELAND, OHIO

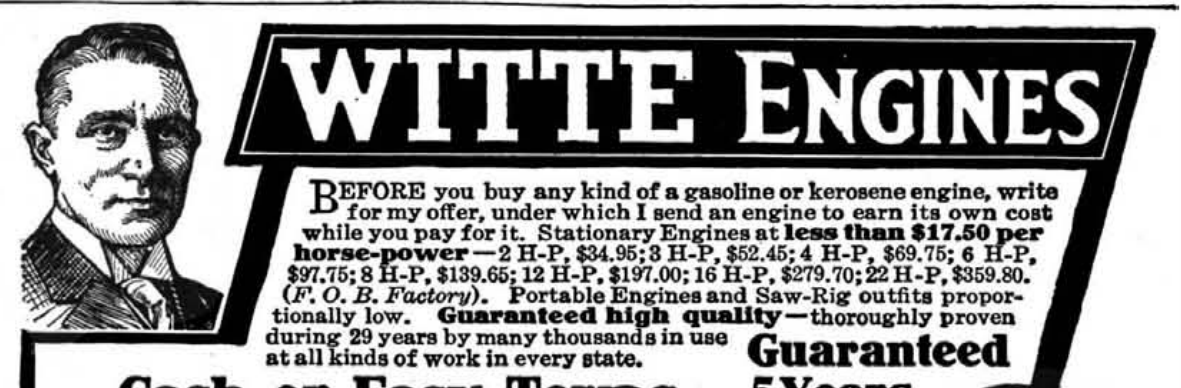

Cash or Easy Terms

5 Years

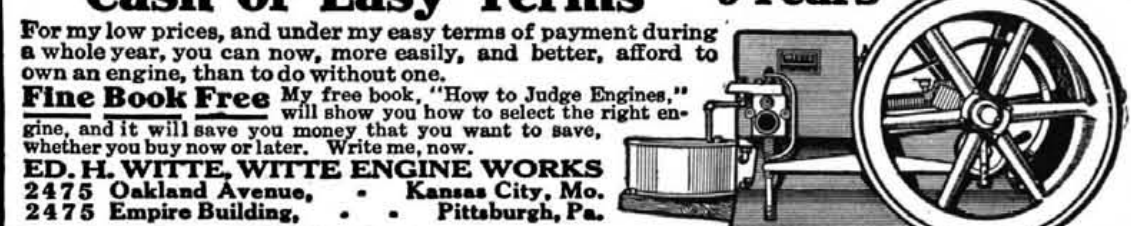




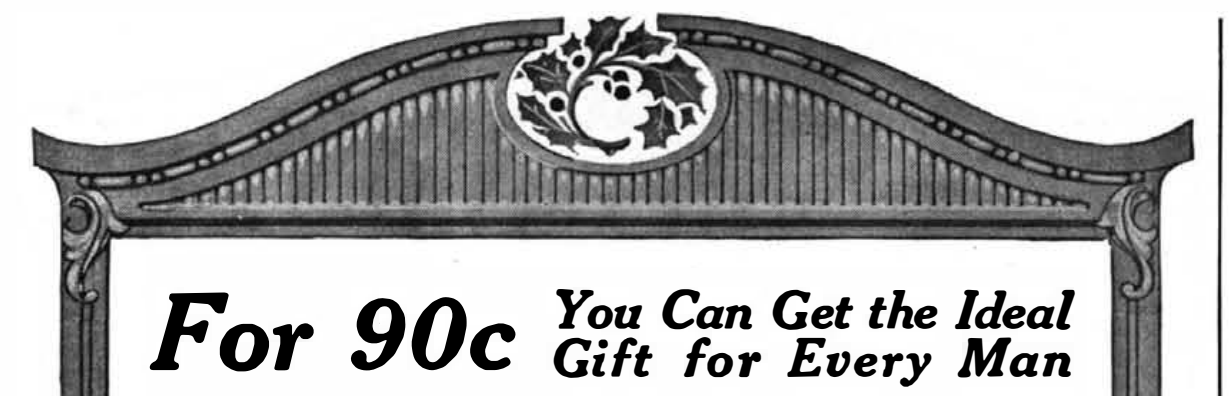

A crystal glass humidor jar containing one pound of Tuxedo, the mildest, most fragrant tobacco.

The spirit of Christmas is the spirit of Cheerfulness and Good Will to Men-and that is the Tuxedo spirit.

Tuxedo is the mildest, pleasantest pipe tobacco in the world - made absolutely non-biting and delightfully mellow by the original "Tuxedo Process" that has never been successfully imitated.

Tuxedo is sold everywhere-but if by any chance you cannot obtain the Christmas Jar of Tuxedo at your store, send us your dealer's name and $90 \mathrm{c}$, and we will send a jar to you or to any address in the United States you desire, all charges paid.

Last Christmas the demand for Tuxedo humidor jars was so great that thousands of people were disappointed. The safe plan is to place your order SOLD IN MANY

CONVENIENT SIZES In Glass Humidors, - 50C and 900 This Tuxedo Christmas Humidor J ar is beautffull Christmas carddo ond packed in Curved Pock In Min isture-Proof
Cloth Pouch, - THE AMERICANTOBACCOCO.

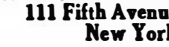

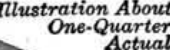
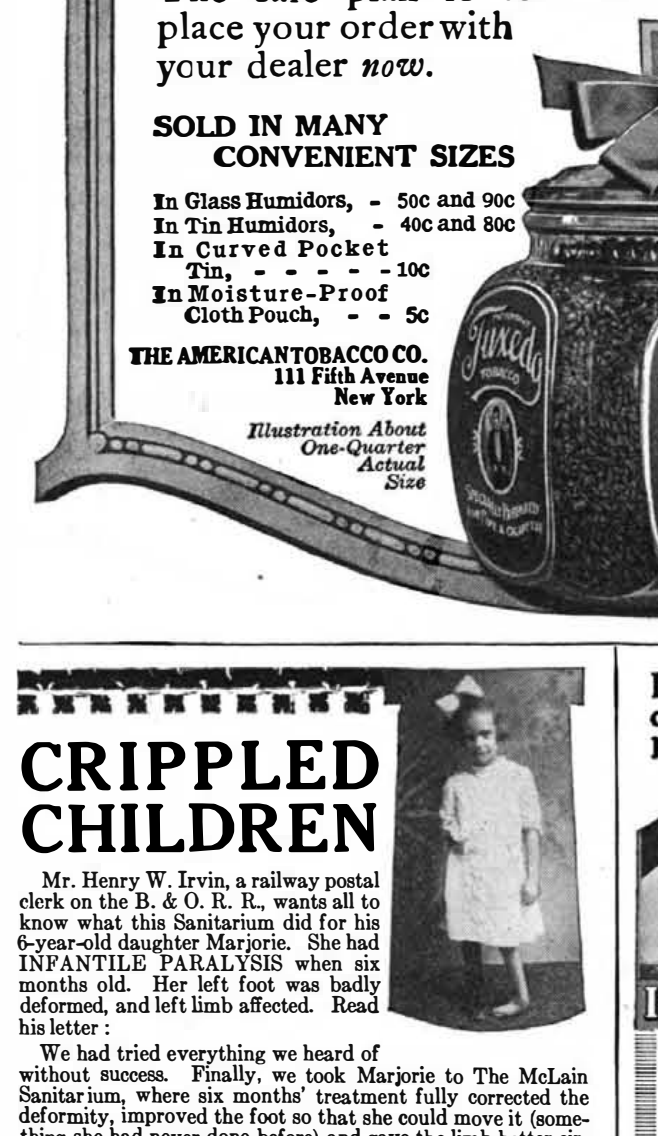

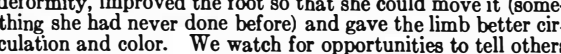
what you did for Marjorie. Don't hesitate to write Mr. Irin and ask questions. Re-
member, for 30 years this private institution has been exclu-

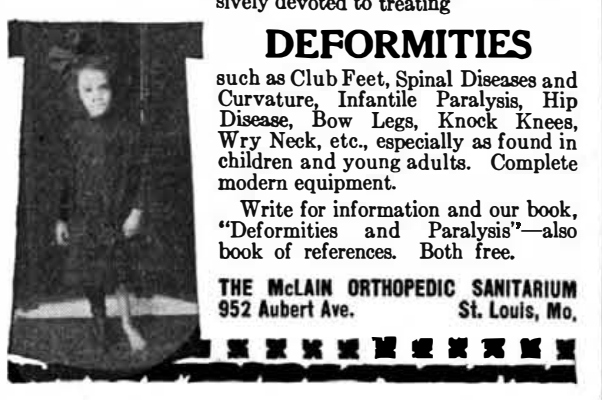

Catalogue of Scientific and Technical Books

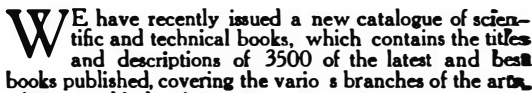

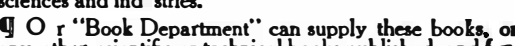

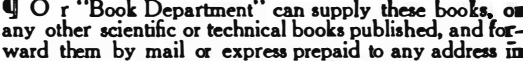

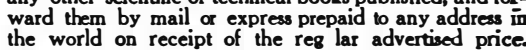
IS Send s sour name and addrese and a copy of thin
catalogue will be mailed to you free of charge.

MUNN \& CO., Inc., Publishers American Office, 233 Broadway, New Y $90 \mathrm{c}$

Isonzo it is surrounded by a group of has held the Italians at bay. Just north of Gorizia the mountain country comes other side of the river, are found the mountains, on one of the spurs of which of Podgora on the same side of the river. This will be somewhat facilitated now by from Plava to the river mouth. Pivoting

Valuable Books of Instruction and Reference

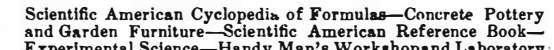
MUNN \& CO., Inc., Pablishers, Woolworth Bldg., New York

LET 'TECLA' DEVELOP IT! Electrical and mechanical devices developed and built by experts. Inventions designed, tested, perfected. Patent Office models. Special machinery and fine instruments designed and constructed. Experimental work, especially railroad signalling, and Radio. Also autoTECLA ELECTRICAL LABORATORY Consulting Electrical and Mechanical Engineers DETROIT, bination of electric oven and the popular heavily intrenched hills, and it is these These hills have been lined with Austrian artillery which up to the present writing down rapidly to the plain on which the city is situated. The Isonzo here come through a deep gorge-like ravine into the open country, and breaking away slightly to the west, follows along the western foot of a large table land, the Plateau of Corso. Directly west of Gorizia, on the is the town of Podgora, below which run both the railroad and the highway into Gorizia. Because of the fact that this highway and railroad cross the river at the foot of the elevation on which Gorizia is situated, and because also of its excellent position for observation and artillery Podgora would seem to be absolutely essential to the Austrian continued possession of Gorizia. It is scarcely a mile and a half away and absolutely dominates Gorizia and the hills in its rear in every way. The northern top of the plain on which Gorizia is situated, while considerably more distant from Podgora than is the city proper, is stil within comparatively short range for heavy artillery and is moreover controlled from the heights of Oslavia north Podgora has therefore been one of the points which have borne the brunt of extremely heavy attacks and is reported, together with Oslavia, to have fallen into Italian hands. If this proves to be true, the fall of Gorizia is much nearer than Austrian reports would lead us to believe. Another point of interest in the fighting along the lower Isonzo is the battle for the Dobrado plateau, some three miles southeast of Gradisca. The Austrian here are well entrenched and have offered a most effective resistance to the Italian advance. The Italians have however secured good foothold on th the capture a few days ago of the heights of San Michele and San Martino de Corso to the northwest of the plateau, both of which are considerably higher than any other points in the vicinity. The fighting on the plateau itself has been trench warfare pure and simple, entirely analogous to the fighting in France. The advance has been extremely slow, is measured in fact in yards. Once Gorizia falls, the way to Trieste is clear. The country between the Isonzo and the railroad entering Trieste from the north is for the most part open and there is not a single fortified place between. From Gorizia there is a railroad ine straight to Trieste which will mark the line of the Italian advance. The Italians, with the bridge head over the river in their hands, will be able to clear all of the west bank of the river of Austrians and will then control this bank there either on Playa or Tolmein, their superiority in numbers will enable them to push across the open country to the south and bring again under Italian rule their citizens who for years have bee looking forward to the day when they should again be living under the flag of King Humbert.

Electric Heating and Cooking Concluded from page 496)

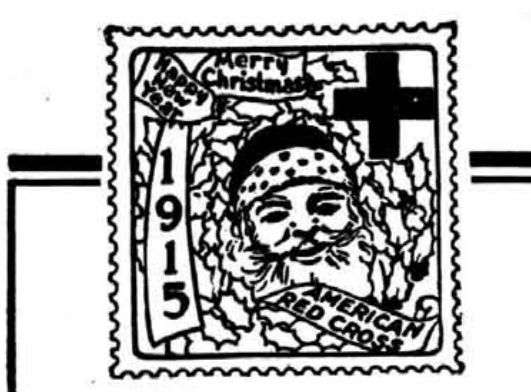

Right in Your Own Town YOUR Christmas Gift Might HELP

Get YOUR share of Christ mas Happiness by helping those who are fighting

Tuberculosis in your country and right in your own state or town.

Every effort you make to destroy Tuberculosis, will save life, add to the wealth of the community, and lessen the tax required for the support of institutions aiding tuberculous patients and those dependent upon them. Help stamp out the dread White Plague by buying Red Cross Christmas Seals. It is your fight-for Humanity's sake. Do your share for your community. Even one seal will

\section{RED CROSS} Christmas Seals

If you cannot buy Red Cross Seals in
your town, write to AMERICAN RED CROSS. Washington, D. C.

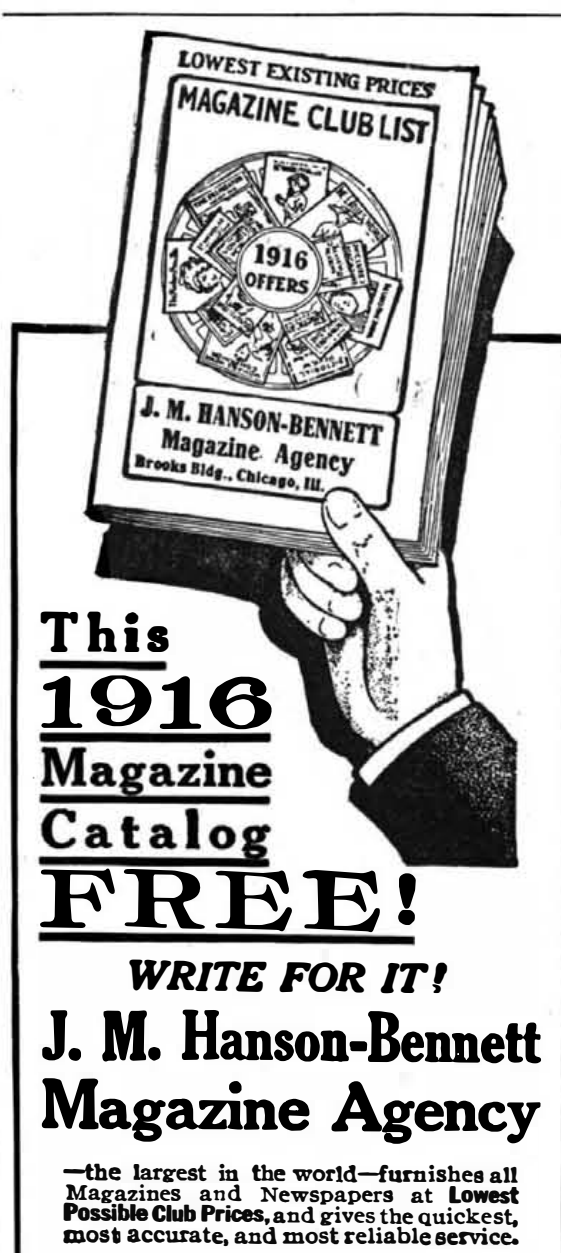

the process is automatic and does not reDuring the lattention of the housewife housewife need not be tied to her kitchen, as all that would be necessary at that time would be to dish up the food and

The electric light and power companie should be interested in perfecting this method of cooking and in bringing it to the attention of their customers. A comfireless cooker would be a very desirable load for the central station. It would be a nearly steady all-day load and would not interfere with the peak load even in the winter, as sufficient heat can be stored
MERICAN, INC

\section{Save Magazine Money!}

\section{Our 1915 Catalog (44 pages) lists more than
3000 Periodicals and Cub Otfers. It's a
Bisg Big Money Saver and is free to you for the
asking. The name $\mathrm{T}$. M. Hanson-Bennett
is ing} Local Agents Wanted
Lomptness in the magazine fied Send U. YOUR TO
Nameand Address ADDRESS

\section{J.M. HANSON-BENNETT}

MAGAZINE AGENCY 